\title{
TYPAL AND TYPOLOGICAL REASONING: A DIAGRAMMATIC PRACTICE OF ARCHITECTURE
}

Sam Jacoby

Architectural Association School of Architecture, UK

This is an Accepted Manuscript of an article published by Taylor \& Francis in The Journal of Architecture on 22.01.2016, available online:

https://www.tandfonline.com/doi/full/10.1080/13602365.2015.1116104 


\section{ABSTRACT}

The twentieth century accounts of typology are often both historiographically problematic and conceptually imprecise. They reinforce an understanding of typology as mainly an interchangeable functional and graphic classification, and present JeanNicolas-Louis Durand as a key figure of the discourse, despite him dealing with buildings according to their genre and not their organisational and structural diagrams of typology. In contrast, one can posit that all theories of type are foremost epistemological and discursive arguments. Although not prescriptive in a formal sense, they are concerned with a rational synthesis of form by thinking through conceptual and diagrammatic organisation. This diagrammatic abstraction became instrumental to architectural theory and history already in the eighteenth century, long before the modern discourse on the diagram was consolidated in the 1990s.

While the architectural diagram is regularly explained as a generic and generative description, it can be equally defined as a typological diagram specific to the architectural discipline and its production of knowledge. Clarifying the concept of type as emerging in parallel with ideas of abstraction and diagrammatic reasoning reveals a richer set of connected problems deriving from architectural practice, pedagogy, and disciplinary knowledge, which permits a different framing of the historical discourse. This is explored by discussing its meaning for a distinction between typal and typological reasoning, how this arises from a problem of history and theory, and how the evolving typological discourse relates to the concepts of invention, disposition, and style. Whereas historiography commonly recognises the French academics AntoineChrysôthome Quatremère de Quincy and Durand, the often overlooked Gottfried Semper and Julien-David Le Roy were central to a modern conception of architecture that developed ideas of typal and typological abstraction through historicist processes of cultural and diagrammatic reduction. 


\section{INTRODUCTION}

The academic discourse on the architectural diagram consolidated in the 1990s. In parts motivated by the technical possibilities of computational design and analysis, it theorised design processes and problems of formal invention through the abstractions of the 'generative' diagram. Despite emerging differences in definition, a common ground to the debate was an agreement that a new diagrammatic practice had to explain, analyse, organise, and generate beyond the limits of classical representation. ${ }^{1}$ This, so its claim to originality, liberated architecture from imitative repetition, gave it autonomy (one not always already historicised), and produced something entire different if not new. ${ }^{2}$ The explanations by key proponents of the diagram, such as Peter Eisenman, Stan Allen or Robert Somol, were complicated by an avant-garde rejection of representational 'traditions' while, at the same time, upholding that the diagram had to somehow register architectural context, site, programme, history, and discourse. Predictably, typology defined as a classificatory study of buildings with shared functional and morphological traits, was seen as epitomising what the abstract diagram is not: a restriction of generative and transformative reasoning by a pre-taxonomised translation of conceptual and graphic thinking into materiality and architectural objects. ${ }^{3}$

'Diagrams underwrite all typological theories, as evidenced, for example, in the catalogues of Durand', writes Jeffrey Kipnis, suggesting that typology does not exist without the graphic diagram. ${ }^{4}$ This statement-whose assumptions are shared by most advocates of the generative diagram-reveals two flaws useful to the following discussion. Not only can one equally assert that a typological problem underwrites all architectural diagrams, but also Jean-Nicolas-Louis Durand did not deal with typology - he abstracted buildings according to their genres (function) and was unconcerned with typologies defined by comparable organisational and structural diagrams of buildings. In addition, one can ask if there is more than a graphic diagram. Yet Kipnis's mistake to employ typology in an interchangeable functional and graphic sense is common to its twentieth-century use. 
The Modern Movement deliberately reduced the nineteenth-century doctrine of type to the functional classification of buildings to avoid its connotations of style, thereby consciously eradicating distinctions between type and genre, but also type and typology. When Giulio Carlo Argan 'rediscovered' the notion of type in his article 'On the Typology of Architecture' of 1962, he revisited its first definition by AntoineChrysostome Quatremère de Quincy, stating that a 'typological series'-a series of cases linked in their formal development-is determined by function and configuration, and 'has to be understood as the interior structure of a form or as a principle which contains the possibility of infinite formal variation and further structural modifications of the "type" itself'. ${ }^{5}$ Argan's description of type as a form of knowledge internal to architecture provides a rational explanation of the relationship between a historical process and an architect's individual design through a specific typological solution. This explanation is autonomous from other disciplines, and complemented a return to questions of historical and contextual continuity in post-war Italy. His interpretation informed the ensuing typological discourse in Neorationalism, which, critical of Modernist planning, saw the city and its elements not as a planning but design problem, whereby a regulating typology linked to urban morphology to analyse context, programme, and history could be mobilised. ${ }^{6}$ But, as Werner Oechslin argues, Argan was also to blame for a widespread misconception of typology as iconology and its decline to received forms. ${ }^{7}$ Although at first typology seemed to offer a sustainable 'post' Modernist design practice-an analytic architectural theory and urban science as Aldo Rossi proposed in The Architecture of the City (1966)_its failure was by the 1980s widely accepted. Typology had become 'a low level of theory' providing little more than fixed historical answers. ${ }^{8}$ Its use by the new discipline of urban design conventionalised functional classification and graphic explanation of form.

Coinciding with a growing interest in design method, the spreading of the Neorationalist theory of typology to Europe and America strengthened a focus on methodical classification and design. This also applies to Alan Colquhoun, who, inspired by Tomas Maldonado, in 'Typology and Design Method' (1967) is the first English-speaking theorist to examine the notion of typology. Colquhoun contends that a final configuration of form is never entirely an outcome of scientific deduction and involves aesthetic intention. This intention, if it is more than intuition, has to acknowledge past design solutions. Thus, typological models as repositories of existing formal solutions 
and social meanings become necessary, but have to be adapted to a contemporary context. Similarly, another important contributor to the English-speaking debate, Anthony Vidler reinforced the narrative that typology is a problem of defining ideal typesolutions, although he believes this was overcome by Neorationalism. ${ }^{9}$ In 'The Third Typology' (1976), he sketches out three uses of typology. The first developing from an imitation of nature to a scientific classification (from Marc-Antoine Laugier's primitive hut to Durand's collections of buildings), which also underlies the functional classification of economic production by the Modern Movement and, third, a Neorationalist understanding of typology as an analytic of the city through which the 'unitary statement' of form and function is transformed to an open possibility of designing public architecture.

The discussed definitions of typology are largely consistent. The contemporary accounts of typology, such as Vidler's, permit the firm inclusion of Durand in the discourse-which seems necessary to explain a functionalist and graphic definition of typology_but are both historiographically problematic and conceptually imprecise. The notion of 'type' formally entered architectural terminology only with the publication of the third volume of the Encyclopédie méthodique: Architecture by Quatremère in 1825 , where he presented it as an idea in contrast yet complementary to the model. Thus, considerably later than either Durand's Collection and Parallel of Buildings of Every Genre, Ancient and Modern: Remarkable for Their Beauty, Their Grandeur, or Their Singularity, All Drawn to the Same Scale (1799-1801) or the Précis of the Lectures on Architecture given at the École Polytechnique (1802-5) that studied the abstraction and derivation of buildings according to genres. Quatremère introduced the term type to overcome two principles that he saw as preventing a modernisation of architectural practice and knowledge: imitative representation and first origins. They were characteristic for the Beaux-Art idea of the artistic model and stood for a traditional theory of the arts and their teaching. As a modern concept, type replaced previous categories of classification, such as character and genre. Yet throughout the nineteenth century, its idea underwent continuous transformation in meaning, perhaps due to the formal vagueness ascribed to it by Quatremère.

However, it can be posited that all theories of type are foremost epistemological and discursive arguments. Although not prescriptive in a formal sense, they are concerned 
with a rational synthesis of architectural (and urban) form by thinking through conceptual and diagrammatic organisation. A concern with the discursive potential that exists in the space from conception to formal realisation. It is a diagrammatic abstraction that became instrumental to architectural theory and practice already in the eighteenth century. This defines the architectural diagram not just as a generic and generative description, but also as a typological diagram specific to the architectural discipline and its production of knowledge. In this context, Durand's graphic work closely relates to a problem of type. The connection of type and diagram requires a distinction between a conceptual (typal) and formal (typological) reasoning, consistent with the one between idea and model found under the rubric 'Type' by Quatremère. Through a typal reasoning, form acquires manifold historical, social, political, cultural, and symbolic dimensions limited by but, importantly, also in excess of material reality. The material and typological organisation of these social diagrams is in turn the concern of spatial and graphic diagrams, which can also be termed typological diagrams.

To explain the premise of a typal and typological reasoning and their relation to forms of abstraction, one has to examine how this distinction and interrelation relates to a separation of history and theory. How theories of type are framed by problems of invention, disposition, and style-the first three principles of transformative composition in rhetoric-through which arguments are conceived, structured, and delivered, or considered as equally made up of conceptual, formal and social aspects. To clarify the concept of type as emerging in parallel with ideas of abstraction and diagrammatic reasoning reveals a richer set of connected problems that derive from architectural practice, pedagogy, and disciplinary knowledge, and a different framing of the historical discourse. Whereas historiography commonly recognises the French academics Quatremère de Quincy (1755-1849) and his contemporary Durand (17601834), the German architect Gottfried Semper (1803-1879) and the French archaeologist Julien-David Le Roy (1724-1803) were central to a modern understanding of architecture that developed from the typological discourse, but both are overlooked in all key historiographical reviews. ${ }^{10}$ Similarly Le Roy's formative influence on Quatremère's historical relativism, from which his theory of type derives, has remained unnoticed. ${ }^{11}$ The three inaugural theories by Quatremère, Durand, and Semper, despite different conceptions of type, share an understanding of form through 
abstraction. Their historicist interpretations of form argue for a momentary autonomy that arises from architecture's constitution as an independent formal and artificial language. In their theories and design studies, mimetic imitation is replaced by memetic, conceptual, and symbolic abstraction as well as a diagrammatic reduction that emphasises the interactions between type and diagram, abstraction and translation, and idea and model. Therefore I will discuss what this means for an understanding of type and typology, how this arises from a problem of history and theory, and how the evolving typological discourse relates to the concepts of invention, disposition, and style.

\section{THE HISTORY AND THEORY OF ARCHITECTURE}

A rising empiricism in the seventeenth and eighteenth century put architecture's widely held belief in classical authority into crisis. The need for modernisation led French architecture to foster a modern canon tasked with consolidating past theory and evolving practice. This relied in its studies of historical precedents and contemporary architecture on empirical methodologies borrowed from emerging scientific archaeology and dealt with problems of construction, often arising from new civic structures and buildings. Recognising the waning of traditional explanations, Claude Perrault therefore proclaims at the end of the seventeenth century:

Hence, neither imitation of nature, or reason, nor good sense in any way constitutes the basis for the beauty people claim to see in proportion and in the orderly disposition of the parts of a column; indeed, it is impossible to find any source other than custom for the pleasure they impart. ${ }^{12}$

Perrault effectively declares an end to prevailing cosmological rationality and compels a historicist relativism, however, one that can explicate the relevance of historical precedents to current practice. This conception of conventional and relative architectural styles required a new historiography. Thus by the late eighteenth century, the claim of classical authority to universality was forever destabilised by historicism and a recognition of individual expression and cultural diversity. 
Critical for the historicist reassessment of architecture was Le Roy, who published The Ruins of the Most Beautiful Monuments of Greece in 1758. In the book, he was the first to introduce the concept of 'history' to architecture by distinguishing it from architecture's theory. This clarified the difference between a theoretical system of principles, which Le Roy divides into three classes according to general and common architectural ideas, and introduced history as the framework through which a development of these principles can be understood. ${ }^{13}$ The first class contained universal principles related to practical problems of construction and utility, the second comprised of principles of perception and aesthetic judgement, and the third referred to principles depending on climate, available building materials, and customs. These geographically and culturally specific factors are therefore only selectively accepted, nevertheless account for the variety of styles and formal differences. History, so Le Roy, registers the development of architecture and its 'primitive ideas' in a series of connected positivist and individual transformations. This relativises the problem of origins, as higher artistic achievement of some people and cultures over others is measured by a qualitative change and is not a simple question of chronology.

Le Roy analysed formal development through taxonomic comparison, in order to determine relative stylistic periods and artistic achievements. He thereby noticed that stylistic changes depended throughout antiquity on socio-cultural, geographic, and climatic contexts and described a progressive yet nonlinear process of historical contingency and exchange. ${ }^{14}$ But the irreversible conflict between representation and reason after empiricism required a distinction between history and theory. When history effects an architectural object, with its historicalness characterised by the different contexts it registers, it also contextualises and effects the principles of architecture, its theory. This makes a separation of history and theory necessary, and arising from a tension between them, architecture exists then simultaneously as a general (theoretical) and specific (historical) object that belongs both to the past and present. As Le Roy explains in the second edition of The Ruins: 'It is these differences, these affinities, these successive transitions from one perfection to another that we intend to demonstrate in the present essay.' ${ }^{15}$ To synthesise a metaphysical general and a formal specific, means to read the architectural object as a historical object that is judged by its presence (whether in the past or present), but also as belonging to a 
continuous development of form. This on-going transformation is limited by 'primitive original ideas', which due to their persistence throughout history can be deemed ahistorical and as providing common criteria to the abstraction of a series of buildings deriving from them. Formal development is effectively seen as occurring along a typological line of development, with all instances sharing a comparable diagrammatic trait. Consequently, comparative diagrams serve typological analysis and a judgement of individual form against a theoretical possibility of form. They offer a simultaneous theoretical and historical analysis of form, and suggest a separation and synthesis of the knowledge that typal and typological reasoning make available.

The Ruins was significantly revised for its second edition in 1770, incorporating an advanced argument of architectural history developed by Le Roy in the treatises History of the Disposition and Different Forms That the Christians Gave to Their Temples since the Reign of Constantine the Great to Our Own Day (1764) and Observations on the Buildings of Ancient Peoples (1767). His idea of analysis is particularly apparent in the History that summarises the evolution of churches in a comparative plate through the juxtaposition of their plans and sections (Fig. 1). Evocative of a Linnaean taxonomy, the matrix provides the arguments later adopted by all claims for an evolution of architectural form: a process of methodical reduction and a diagrammatic explanation that relies on comparison. While a graphic comparison of scaled plans itself is unoriginal, Le Roy's use differs from earlier instances, as his interest is not size, stylistic detail, or chronology, but formal relations that describe a sequence of transformation and permit their judgement. ${ }^{16}$ Published to demonstrate the superiority of Jacques-Germain Soufflot's design for Sainte-Geneviève over comparable designs, the church is depicted in the centre of the plate as the synthesis of three developments, whose typologies are: the cross-shaped plan, parallel rows of freestanding columns in the basilica, and the dome. Explaining the importance of graphic abstraction to the representation and analysis of architecture, Le Roy states: 'A figure, even a small one, will better transmit an understanding of a building and will more promptly communicate its disposition than the most thorough verbal description.' ${ }^{17}$ 


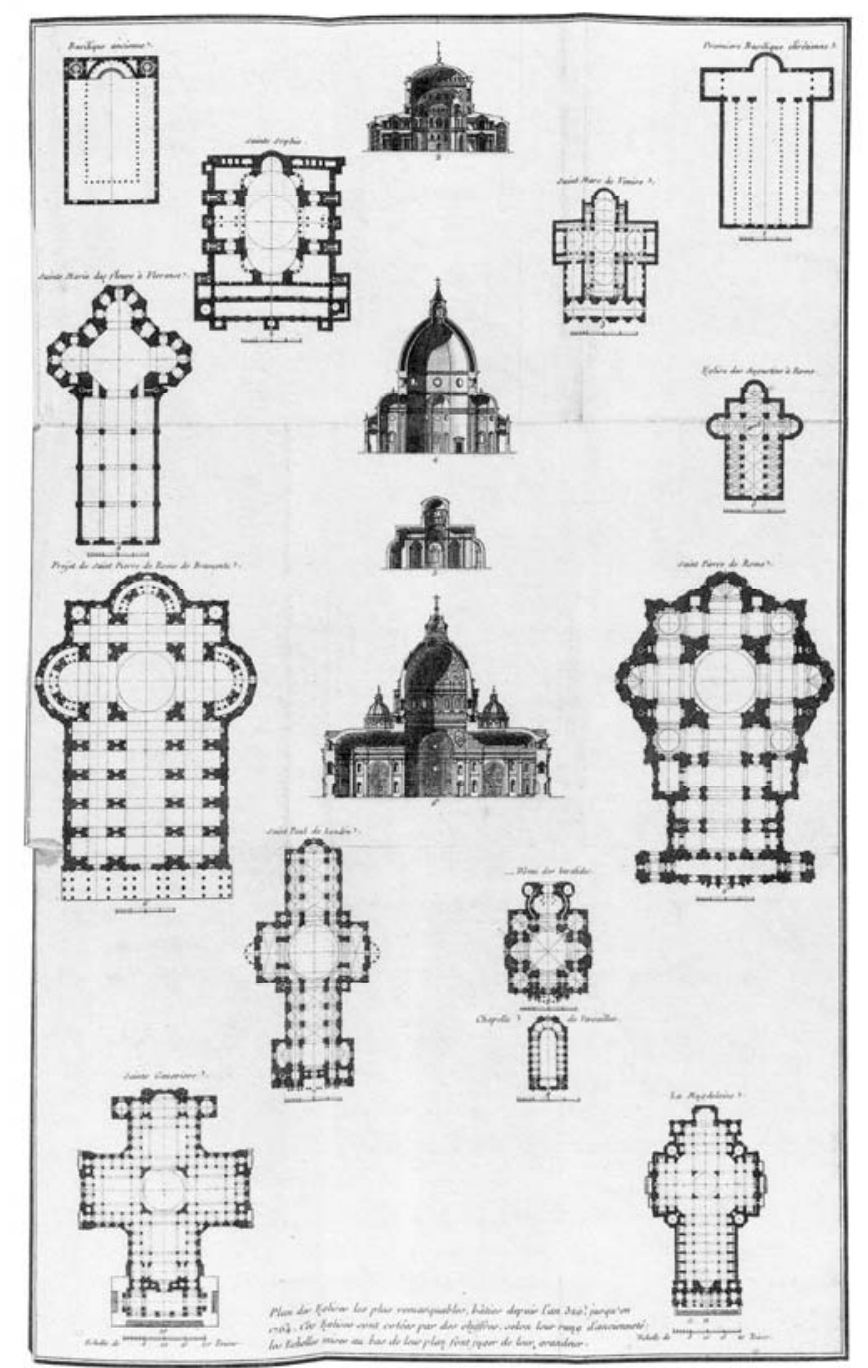

'Plan des églises les plus remarquables bâties depuis l'an 326 jusqu'en 1764' [Plans of the Most Remarkable Churches Built from 326 to 1764] by Jean-François de Neufforge, in Julien-David Le Roy, Histoire de la disposition et des formes différentes que les Chrétiens ont données à leurs temples depuis le règne de Constantin le Grand jusqu'à nous (Paris: Desaint \& Saillant, 1764)

Examining the historical changes of the temple type in The Ruins (1770), Le Roy introduces yet another important diagrammatic plate (Fig. 2). Organised into three columns, it compares the sequential transformation of Egyptian and Phoenician, Greek and Roman, and Christian huts into temples with increasing size and detail. The diagram is accompanied by an extensive text explaining the relation of each instance to its precedent in the imagined line of development that is depicted. Despite its chronological appearance, which implies a linear development, the plate compresses different historical developments into one comparative matrix, regardless of chronology. Visible differences between instances manifest the contextual responses through which history inflects the theoretical form of architecture. ${ }^{18}$ 


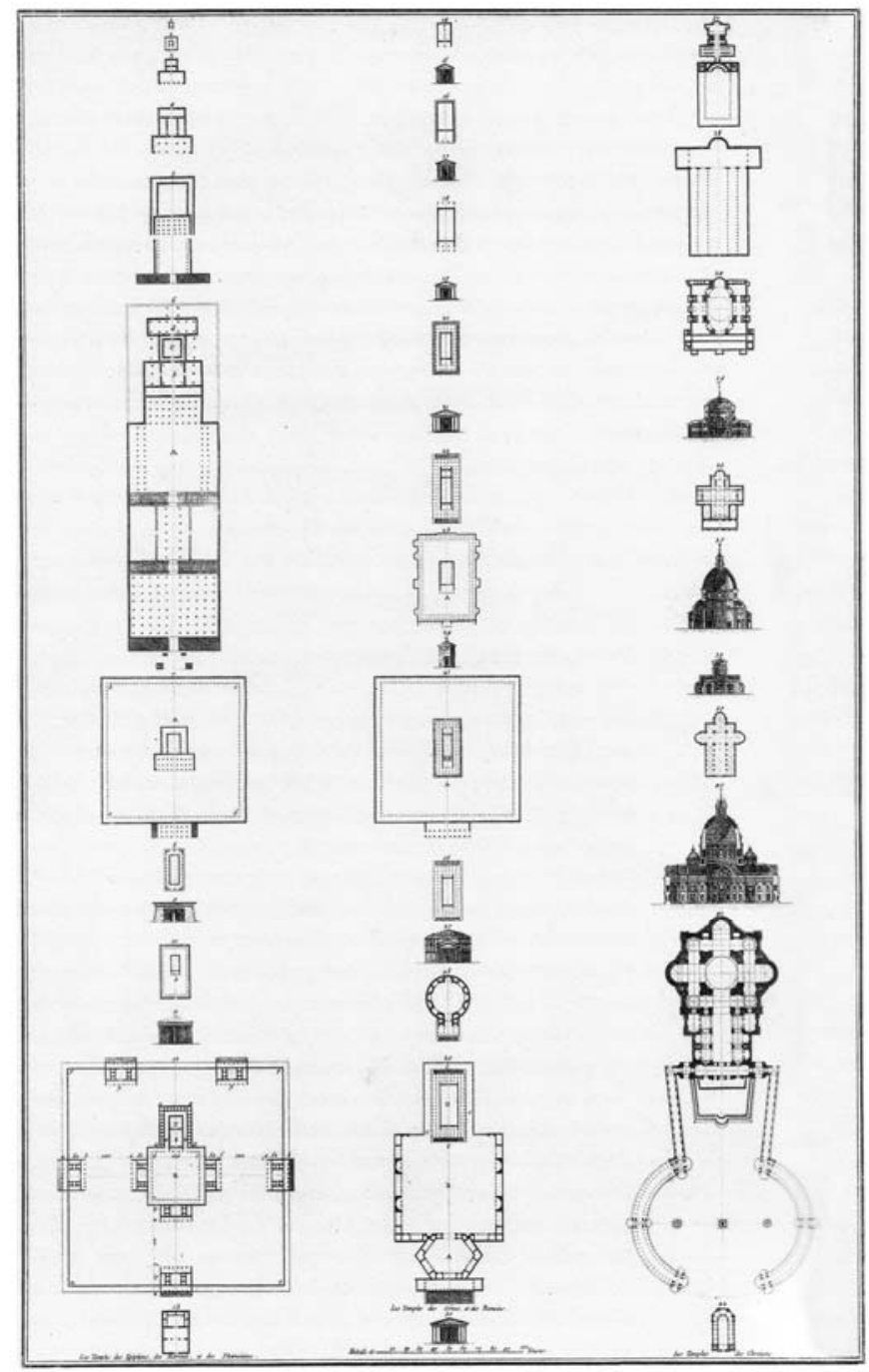

'Plate 1' by Michelinot after Le Moine showing the parallel formal development of the temple, in JulienDavid Le Roy, Les Ruines des plus beaux monuments de la Grèce: considérées du côté de l'histoire et du côté de l'architecture, 2nd edn (Paris: Delatour, 1770)

Le Roy's work asserts a productive relationship between architectural form and historicity, proposing that form is historically specific and part of a larger and enduring theoretical discourse. However, his interest is not to resurrect the past, but to didactically use formal abstraction and historical knowledge to explain contemporary disciplinary enquiry. To demonstrate how invention and disposition are closely related in the development of form and can be methodically analysed and described. His thesis of history prepares a modern reasoning that Michel Foucault characterised as 'the emergence of history as both knowledge and the mode of being of empiricity'. ${ }^{19}$ 


\section{INVENTION}

Quatremère in his winning submission for the Prix Caylus of 1785 closely follows Le Roy's position on development. Similar to Le Roy, who devised the theme and judged the competition, he claims in the Mémoire on the Question: What Was the State of Egyptian Architecture and What Do the Greeks Seem to Have Borrowed from It? that the development of the tripartite origins of architecture in the cave, hut, and tent was connected, despite emerging sequentially and in parallel in different cultures. After editing the Mémoire for publication under a new title, On Egyptian Architecture, Considered with Respect to Its Origin, Its Principles and Its Taste and Compared in the Same Terms with Greek Architecture (1803), Quatremère radically overturned his earlier conclusions. He now proposes common but multiple origins within different cultures without any developmental connections. Unlike Le Roy's positivist development of typologies, it suggests an organic system of types. Architecture had conceptually transformed from a natural to an artificial language with many filiations. The fundamental revision emphasised a process of intellection through socialisation and enculturation, which defined architecture and its knowledge production as a sociocultural appropriation unique to a society. ${ }^{20}$

Quatremère's changing understanding of origins coincides with his appointment as editor of the first French architectural dictionary, the Encyclopédie méthodique: Architecture (1788-1825), in 1787, which required him to integrate architecture within a new classification of knowledge that placed it amongst the fine arts. ${ }^{21}$ This meant that he had to respond to the prevalent discourse of imitation, the conventional framework to discuss artistic invention. To this debate on imitation, Johann Joachim Winckelmann's modern art history-influenced by Le Roy's contextual reading of artworks and their taxonomic comparison-was seminal in challenging imitative principles, as he judged creativity as an abstraction of nature and not in classical terms as a skilfulness to represent nature. Despite these precedents, Quatremère faced a difficult double task. He had to establish architecture as an imitative fine art and deconstruct its means of imitation.

Through the art historical discourse, he understood architectural imitation in relation to the ideas of the ideal, resemblance, pleasure, convention, and invention, eventually 
arguing against the still definitive principle of origins. He concluded this in An Essay on the Nature, the End, and the Means of Imitation in the Fine Arts of 1823, in which he defines imitation and invention as an intellectual abstraction requiring a re-composition of reality through a vision or artefact that is socio-culturally specific and conceptually ahistorical-showing the influence by Le Roy. It defines the arts as a form of typal reasoning, with their production less a formal than a cultural abstraction that, although limited by the practical and technical means available to each art, is principally only constrained in its representation by social utility. While art is bound to a permanent social contract, the production of artefacts is continuously transformed by changes in technology, new materials, and cultural contexts. Developing Le Roy and Winckelmann's art historical theses, Quatremère considers imitation accordingly not aesthetically but:

[...] abstractedly, that is, under a general and theoretical, and not a limited and practical point of view, the words I may employ should be understood only as in a sense related to the nature of an abstract theory, that is, one which generalizes ideas. ${ }^{22}$

This non-mimetic, abstract quality was exemplified by artificial languages, especially rhetoric. As architecture lacks a natural ability to imitate nature, its representations require abstraction, which, so Quatremère posits, make the principles of transformative composition in rhetoric available to architecture. Thus, architecture equally establishes an artificial language. Representing a paradigm, pattern, and standard, type provides to this language the important capacity to name, define, and communicate the otherwise unknown-an abstract theory. In this sense of generalising abstraction can Quatremère's otherwise confusing use of 'imitative' be understood, when stating that this communication is achieved by an imitative resemblance, in which an abstract idea is translated into an engaging artefact. An artefact that due to the limitations of architectural representation is always partial (in a naturalistic sense) and 'produced with and by means of elements distinct from the elements of that object', indicating that the realisation of an artefact is a 'fictitious' interpretation that simultaneously refers to and differs from the object it represents. ${ }^{23}$ In this process, a generalisation through abstraction becomes translatable into a generating type or conceptual idea, which has the ability to obtain a knowledge unattainable to literal representation and 
resemblance. Therefore, the incompleteness of representation is desirable as it necessitates abstraction, and a precondition to decoding a typal idea in a typological model. With the work of art principally unconstrained in its possible form, and imitative resemblance signifying the abstraction of an 'original type', what becomes operative is 'the principle of an abstract existence, of a nature very far removed from the principle of identity'. ${ }^{24}$

Developing in the Essay on Imitation a system of abstract types against which material objects are judged, Quatremère applies this conceptual diagram to architecture in his dictionary entry 'Type' of 1825. The synonymity of the notions 'image' and 'idea' (and 'ideal' as an adjective of idea) is, as he points out, apparent from its etymological roots, with idea deriving from the Greek eidos and eidolon that denote respectively a conceptual type or Platonic Form and a physical apparition. ${ }^{25}$ Thus in 'Type' he famously states:

The word type presents less the image of the thing to copy or imitate completely, than the idea of an element which must itself serve as a rule for the model. [...] The model, understood in the sense of practical execution, is an object that should be repeated as it is; contrariwise, the type is an object after which each artist can conceive works that bear no resemblance to each other. All is precise and given when it comes to the model, while all is more or less vague when it comes to the type. ${ }^{26}$

While models have apparent rules, type represents a non-prescriptive 'idea', 'motif', and 'intention'. Type organises while the model structures. And typological models serve a formal translation of speculative and non-material typal ideas. Contemplating the closely related problem of invention, Quatremère concludes: 'Everything must have an antecedent; nothing whatsoever comes from nothing, and this cannot but apply to all human inventions.' ${ }^{27}$ These 'pre-existing seeds' are found in formal precedents and elementary principles, which as moral (intellectual) inventions are always obligated to sentiment and taste. Accordingly, type is like a sort of nucleus around which are assembled, and with which are consequently coordinated, all the developments and the variations of form to which the object was susceptible'. ${ }^{28}$ Although Quatremère 
never explicitly explains how this formal variation is to be derived in practice, this is a problem that, to some extend, was developed by Durand before him.

\section{DISPOSITION}

Quatremère's typal reasoning in which conceptual abstraction is the basis to 'invent' a disciplinary diagram of knowledge is complemented by Durand's preceding examination of architectural disposition that suggests a form of typological reasoning. He describes architecture in functionalist terms as the formal disposing of parts, and his comparison of abstracted historical forms made their reduction to formal diagrams a means of analysis and design.

Accompanying his lectures at the École Polytechnique, Durand published the Collection and Parallel (1799-1801), which in some editions included the Essay on the General History of Architecture by Jacques-Guillaume Legrand. ${ }^{29}$ A student of Le Roy, Durand was influenced in his abstraction of function to graphic diagrams by the analysis of historical form through typological comparison. But Durand owed methodologically more to a comparative method of classification by the zoologist Georges Cuvier. This allegiance was in no uncertain terms asserted in Legrand's essay, claiming that through structural and formal analysis a 'natural history of architecture might be created'. ${ }^{30}$ Corresponding to Cuvier's comparative taxonomies in which history was reduced to formal and functional descriptions that lend themselves to scientific analysis, and through which physiognomic development could be reconstructed and explained, the ambition of the Collection and Paralle/ was to equally employ history scientifically in architecture. Promising objectivity, technical drawing rather than perspectival renderings provided the means to analyse formal development. With history in the natural sciences defined as rational, as directly linked to verifiable structural development, Durand considered the effects of style and character on buildings as secondary and mere cultural phenomena. In their place, structural relations and, implicitly, formal complexity became a material verification of historical progress. 
Durand developed the ideas of the Collection and Parallel in his Précis (1802-05) by devising a design method simple to follow and instruct. As the Précis declares, its method applies to the design of any building. Durand's architectural course at the École Polytechnique is therefore described as 'the pursuit of certain ideas that are few in number but general in application, and from which all the particular ideas would necessarily derive', outlining a 'safe and rapid way to compose and execute buildings of all kinds, in all places, and at all times'. ${ }^{31}$ Despite Durand understanding these generative ideas in terms of function and differentiation of structure and not through structural comparison, an affinity to the typological problem is evident. Yet Durand justifies his generic method of design through common problems of utility. To achieve utility, architecture has to be fit for purpose and maintain economy of means. According to Durand, fitness derives from solidity (the right use of materials), salubrity (the right choice of site and building exposure), and commodity (the right disposition of the building), while economy relies on symmetry, regularity, and simplicity.

Durand's design method relies on planar dispositions, with a horizontal plan informing its vertical section. The disposition of a building and its elements develops from regular grids and axes-a grid of parallel interaxis determined by the efficient structural distance of two columns, according to which the building elements are distributed. Subdividing the initial grid and omitting, adding, or offsetting one axis differentiates the structural elements of a building. This creates unlimited part-to-part and part-to-whole combinations of building elements and results in a mutation of the building parti, as 'Plate 20' demonstrates (Fig. 3). Despite the procedural nature of design, fitness of the composition, so Durand, is also determined by the contextual requirements of 'places, persons, sites, costs, and so on'.32 


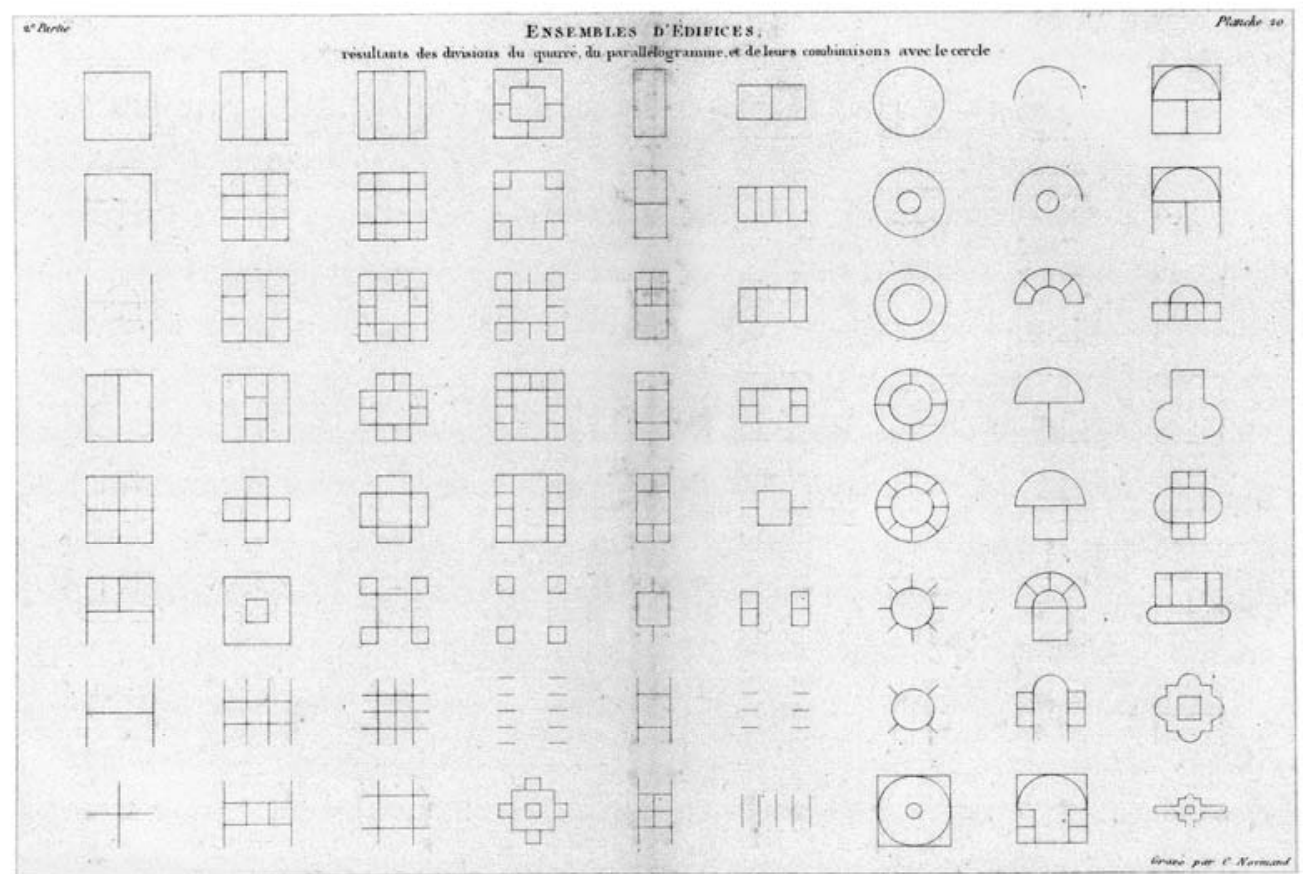

'Plate 20, Ensemble d'édifices, résultants de divisions du carré, du parallélogramme et de leurs combinaisons avec le cercle' [Building Ensembles, Resulting from the Divisions of the Square, the Parallelogram and Their Combinations with the Circle], in Jean-Nicolas-Louis Durand, Précis des leçons d'architecture données à l'École Royale Polytechnique, vol 1 (Paris: the author, 1802)

According to the method, once a plan is derived, the sections can be developed through similar vertical combinations and, subsequently, plan and sections determine the elevations. This sequence of design also exposes a basic problem of the method. As the orthographic drawings of 'Plate 21 ' reveal, which shows supposedly a method applicable to all architectural disposition, Durand's plan-based process cannot logically justify elevational drawings (Fig. 4). In order to determine these, conventions on scale and mass are needed. The elevations and by implication the parti itself cannot be produced by the proposed design method and rely on motivating precedent, as a dome is unexplained by transformations of a planar grid. ${ }^{33}$ 


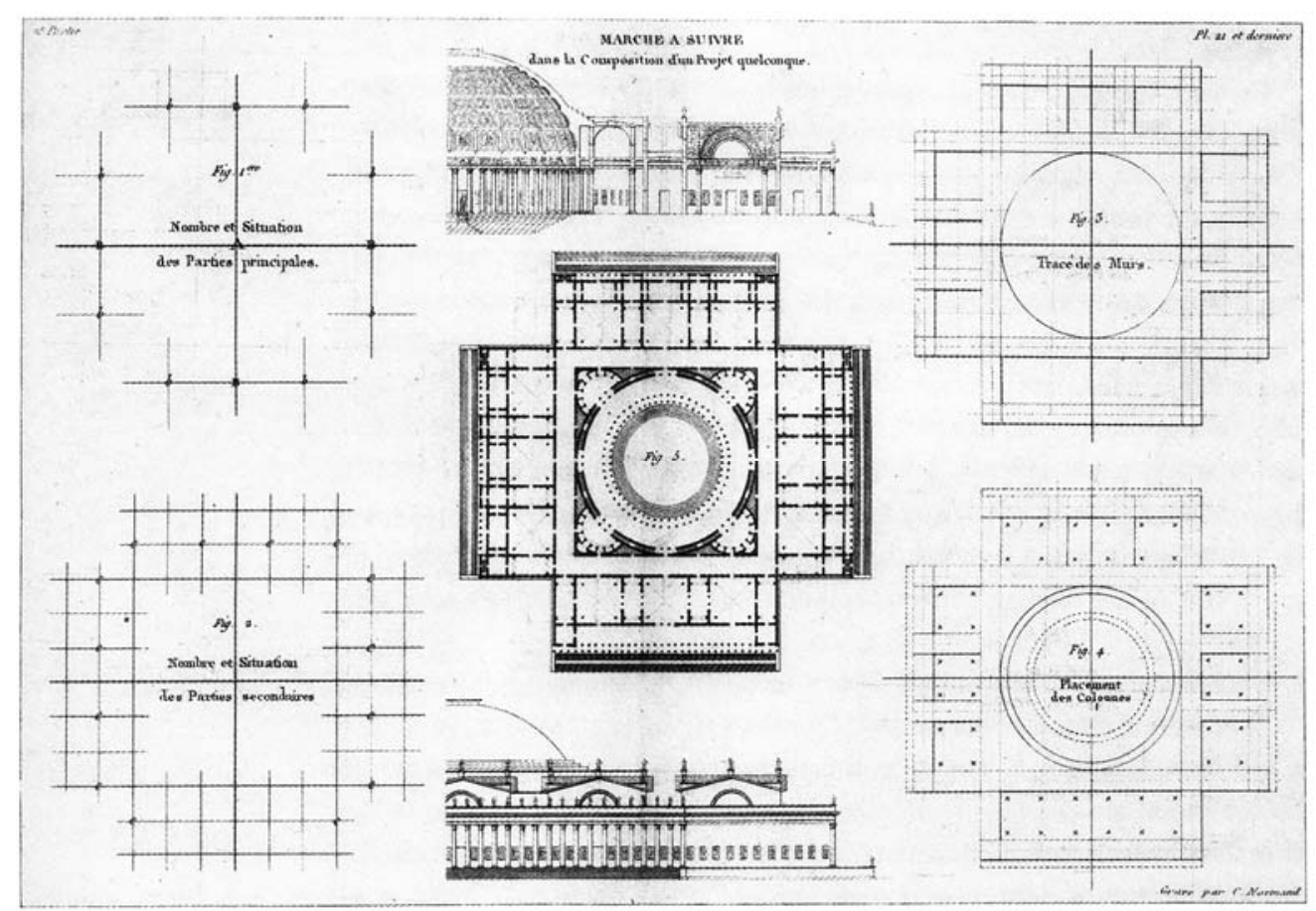

'Plate 21, Marche à suivre dans la composition d'un projet quelconque' [Procedure to Be Followed in the Composition of Any Project], in Jean-Nicolas-Louis Durand, Précis des leçons d'architecture données à l'École Royale Polytechnique, vol 1 (Paris: the author, 1813 edition)

What is therefore apparent is that the design method of the Précis depends on a differentiation of precedents, which Durand admits to at the very end. He explains in a later addition to the Précis, the Graphic Portion, that there is a difference between learning to compose and composition proper. When learning, a didactic analysis of part-to-part relations and eventually of the parts to the whole is important, however, 'when you come to compose yourself, you must begin with the whole, proceed to the parts, and finish with the details'. ${ }^{34}$ The design method is consequently conceived as didactic and less a method of design than analysis, revealing Durand's interest in a didactic architectural project.

By breaking down the general idea of the architecture into special ideas, and those into particular ideas, in the graphic portion we have broken down the general ideas of buildings into those of their parts, and these in turn into those of their primary elements; then, by working back from the elements to the ensemble of the buildings - that is to say, by analyzing them-we have succeeded in forming a precise idea of them, just as we had first succeeded in 
forming a precise idea of architecture itself by analyzing the general idea expressed by that word. ${ }^{35}$

By abstracting precedents to operative diagrams, Durand is able to deploy received form as contingent and not normative to design. His abstraction of architectural form is, however, premised on an assumption of progression and limited to a taxonomy of known work, as collated in the Collection and Parallel. Borrowing from the sciences, Durand sees architectural knowledge as arising from a diagrammatic and generative understanding of relationships. This gives architectural disposition a formal freedom that, so Durand, is limited by society's need for utility-defining thereby utility as a social agenda. It is this generative understanding of form and functionalist conception of the social, combined with an attempt to find a formal grammar capable of responding to the exigencies of modern society, through which Durand anticipates the programme and failure of the Modern Movement. The adoption of his design method by later discourses of typology, convey the instrumentality and limitation that his graphic diagrams bring to the discipline.

\section{STYLE}

Quatremère's theories of invention and Durand's exploration of disposition represent first forms of typal and typological abstraction that make use of conceptual and graphic diagrams. As complementary forms of reasoning, they became synthesised in Semper's work. Interested in the relationship between conception and materiality, he examined how an abstract type is continuously realised in the material and technical transformation of art-forms. Semper became familiar with Durand's didactic teaching during his studies in the 1820s in Paris, and witnessed a heated debate on polychromy, which was first prompted by Quatremère's The Olympian Jupiter of 1814. Inspired by the problem of polychromy, Semper concluded his own archaeological studies in the Preliminary Remarks on Polychrome Architecture and Sculpture in Antiquity (1834) and Application of Colour in Architecture and Sculpture (1836) with the observation that the arts, specific to their cultural and political context, formally transformed artistic traditions while upholding elemental typal motives in idea (Fig. 5). 


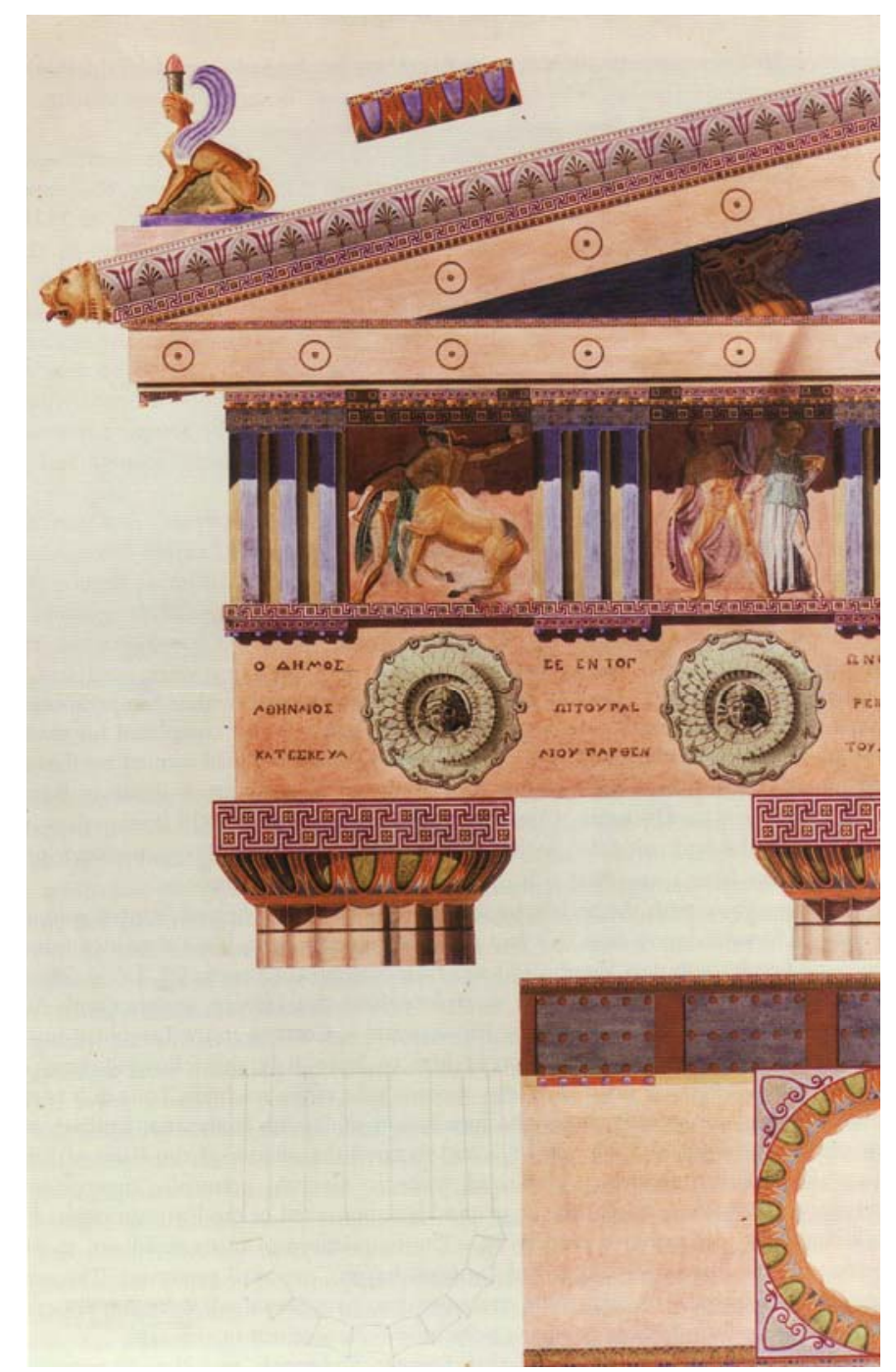

'Giebeldecke vom Parthenon zu Athen' [Pediment of Parthenon in Athens], in Gottfried Semper, Anwendungen der Farben in der Architektur und Plastik (Dresden: Fürstenau \& Co, 1836)

Semper's search for the origins of architecture in typal motives was first articulated in drafts for a never completed book, the Comparative Theory of Building (c. 1840s), and later summarised in The Four Elements of Architecture (1851). They consolidated his 'dressing theory' (Bekleidungstheorie) and 'theory of material transformation' (Stoffwechseltheorie), through which he identified the four elements of architecture (hearth, roof, enclosure, and substructure) and corresponding technical arts (ceramics, carpentry, textiles, and masonry). ${ }^{36}$ Stimulated by the anthropologist Gustav Klemm, Semper's work was essentially a cultural theory of artistic invention, explaining the creative process as a modification of elemental artistic motives through stylistic formal changes. This provided an explanation of the relationship between a typal concept and typological articulation through a problem of artistic design that is not found in either Quatremère or Durand's work. It also developed a concept of abstraction that derived 
from the creative design process itself. Semper concluded his comparative theory of style first in his London writings, in the early 1850s, and a series of lectures held at the Department of Practical Art in London from 1853 to $1854 .{ }^{37}$ It was also in London that Semper saw his thesis of the four elements of architecture represented in a 'Caraib Cottage' from Trinidad, which was displayed at the Great Exhibition of 1851 (Fig. 6).
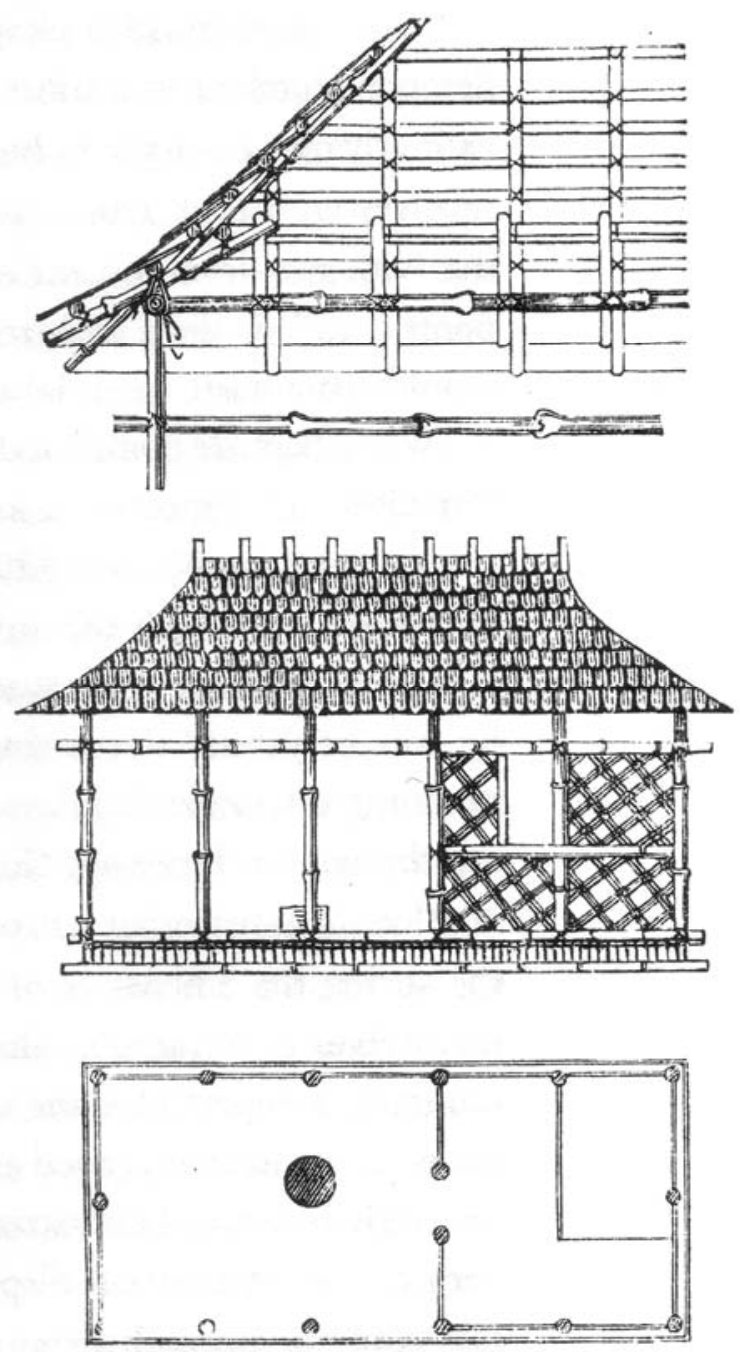

'Karibische Hütte' [Caraib Cottage], in Gottfried Semper, Der Stil in den technischen und tektonischen Künsten, oder praktische Ästhetik: Ein Handbuch für Techniker, Künstler und Kunstfreunde (Munich: Bruckmann, 1863)

In his lecture 'Outline for a System of a Comparative Theory of Style' (1853), Semper proposed a compromise between a typal and typological reading of culture and its history, while formulating a theory of building based on a comparative analysis of elemental types. Stylistic variations, so Semper, were the practical means of necessary utilitarian-material transformations in the becoming of form, disintegrating formal traditions and revealing in their abstraction a symbolic and cultural context. Style in this 
way became important to the definition of a material model and made art relevant to society. Semper demanded in the lecture that architecture should follow the modern sciences and adopt a systematic ordering of knowledge through classification. Recalling his visits to the Jardin des Plantes in Paris as a student, Semper argued that the methodologies of natural history could equally apply to studies of the arts:

They are like those of nature, connected together by some few fundamental Ideas, which have their simplest expressions in types. But these normal forms have given and give rise to an infinite number of varieties by development and combination [...] Will it not be important to trace out some of those types of the artistical forms, and to follow them in their gradual progress from step to step up to their highest development? A method, analogous to that which Baron Cuvier followed applied to art, and especially to architecture would at least contribute towards getting a clear insight over its whole province and perhaps also it would form the base of a doctrine of Style, and of a Sort of topic or Method, how to invent $[\ldots]^{38}$

Like Quatremère, Semper saw elemental types as conceptual diagrams of invention. And appropriating Cuvier, he believed that methodologically a comparison of material formation could clarify invention and its relation to problems of styles. This 'comparative theory' was already discernible in Durand, however, Semper understood it not just as a graphic analysis in the service of formalism, but a means to analyse the motivations of artistic production and their development, insights that could be then applied to design in both functional and conceptual terms. He was also critical of Durand's conception of utility as simply a human function, as he understood it as constantly transformed by changing ornament and technical production, adapting to practical and social human need. Accordingly he declared that the industrial arts gave birth to architecture, and style obtained importance in a work of art by 'observing the limits, which are contained in and defined by the task and problem in question'. ${ }^{39}$

Style motivates typological transformations and reveals underlying typal ideas through its changing means of abstraction. For example, Semper's main architectural thesis of dressing illustrates a process of changing material abstraction, when the spatial covering of wall and ceiling evolve from temporary textile screens into permanent and 
solid walls. Throughout its material transformations, the artistic motive of textile decoration was maintained, not in resemblance but in idea. To Semper this intrinsic relationship between typal idea and typological transformation is also manifest in the etymological roots of the German words Wand (wall) and Gewand (dress), and further supported by archaeological evidence of a developmental link between Egyptian, Assyrian, and Greek polychrome styles in architecture. ${ }^{40}$ This reading of style as a conceptual problem of abstraction and transformation that effects materiality, essentially conforms to one given by Quatremère as 'that which is least material, that is the conception of ideas and the art of developing them according to a certain order'. ${ }^{41}$ Semper, however, focuses on the interrelationship between type and style. Types are to him abstract and necessary forms, whose first materialisation is always modified into new forms of artistic abstractions.

The Styles, which then resulted out of these secondary treatments were composite Styles, which partook on one hand of the types, and the conditions of Style, of the old materials employed for the latter, and on the other hand, they partook of the Style which suits the new selected substance and manner of treatment. ${ }^{42}$

Following a succession of material transformations over time, the effects of type and style become hybridised, with the original artistic motive realised in different materials. Accordingly, the same material has to be able of accommodating different stylistic abstractions. Semper's doctrine of style explicates how the translation of a generic idea into a specific form can be conceived by conflating Quatremère's metaphysical and cultural idealism with Durand's deterministic and utilitarian materialism. He develops a synthesis between typal and typological abstraction in which formal invention is a precondition and an outcome. Consolidating theory and practice, he provides an example of how an abstract, theoretical type can provoke continuous formal interpretations and material transformations, and how a typological comparison makes form available to rigorous analysis. In this sense, his architectural theory conceives form as arising from the combination of social and formal or material diagrams.

\section{CONCLUSION}


Quatremère, Durand, and Semper's theories are consistent with the principles of transformative composition in rhetoric. Quatremère's theory of type articulates the first and indispensable canon of 'invention' (inventio) by establishing a systematic architectural theory of invention that defines the disciplinary means and principles through which coherent arguments are generated in practice. ${ }^{43}$ Durand's method of design in turn is based on the second canon of 'arrangement' (dispositio or taxis), which follows once an argument or idea is strategised by invention. Arrangement manages the relative and iterative ordering of the part to the whole and organises arguments into an effective discourse stating, outlining, and providing proof for a given case or problem. Finally, Semper's doctrine relates to the canon of 'style' (elocutio) by discussing the appropriate and effective modes to express ideas. Whereas invention determines what is articulated, style articulates how it is communicated.

The three theories considered problems of historicity in the architectural work and proposed a resolution through abstraction: conceptually, diagrammatically, and materially. Their mobilisation of history profoundly changed the conception of architecture and revealed type as only conditionally autonomous, at the very moments when through the translation of typal ideas disciplinary knowledge is challenged, changed, and enriched. Prompted by an eighteenth-century transformation of practice and systematisation of theory, architecture became a modern discipline with its own claim to a specific knowledge, which only became possible by distinguishing it from its history. The advent of the notion of type in architecture in the early nineteenth century was instigated by a pervasive obsession with origins and fundamental advances in archaeology, art history, anthropology, etymology, grammatology, and zoology. This highlights that type and typology are unspecific to architecture and interdisciplinary ideas through which knowledge is ordered and obtained. But the instrumentalisation of type and typology in architecture discloses their conception in didactic terms, how theory and practice are imagined as an indivisible material and social construct.

The eventual demise of type in the twentieth-century architectural discourse encouraged a turn to diagrams. However, as Le Roy recognised, architectural diagrams rely on typological production. He also understood that a diagrammatic function depends on abstraction, an abstraction of architectural form that considers 
history, context, and culture as discursive arguments and limits. The typological diagram therefore simultaneously envisions architecture as a specific object and a generic possibility of objects. The diagram limits the possibilities of architectural speculation without determining a finite formal representation. Although diagrams are instrumental to arrange and convey relationships, as the theories of type reveal, diagrams are only intermediaries between conceptual thinking and material representation. Diagrams contribute productively to a tension between type and model by offering a possible synthesis. Accordingly, a formal individuation is a clarification of a typal idea through the translation of a diagram into a possible material manifestation.

By abstracting common organisational and structural diagrams of architectural cases, type can be analysed and projected, as anticipated by Durand and clarified by Semper. This presents, on the one hand, formal solutions receptive to transformation and, on the other, represents a repository of knowledge. Thus, the utilisation of diagrams is essential to conceptualise and analyse form. Although formative to the historical discourse of architecture, types do not require continuity, as evident in Semper's theories, and are defined by transformations through which they effect change. As Alan Colquhoun wrote, to 'understand any given cultural situation, we must investigate its synchronic structure rather than try to explain it exclusively in terms of diachronic development. The synchronic situation always contains traces of the past'. ${ }^{44}$ Types are an integral part of the physical-material, socio-political, symbolic-cultural, and historical conception of our cities and their architecture, but a typal and typological reasoning never just looks at the past and is directed towards the present. While the questions arising with the concepts of type and historicity have defined a modern reasoning of architecture, this was not to establish static norms, rather to advance continuing practice and knowledge. As Semper insisted, artistic progress, despite evolving from past traditions, becomes only possible when traditions are disintegrated by contemporary culture.

\footnotetext{
${ }^{1}$ Compare formative texts such as Stan Allen's 'Diagrams Matter' (1998), Peter Eisenman's 'Diagram: An Original Scene of Writing' (1999), and Robert Somol's 'Dummy Text, or The Diagrammatic Basis of Contemporary Architecture' (1999).

${ }^{2}$ See in particular Peter Eisenman, 'Diagram: An Original Scene of Writing', in Peter Eisenman, Diagram Diaries (New York: Universe Publishing, 1999), p. 31.

${ }^{3}$ A well known example of this normative reduction of building types is Ernst Neufert's Bauentwurfslehre (Architect's Data), first published in 1936.
} 
${ }^{4}$ Jeffrey Kipnis, 'Re-originating Diagrams', in Peter Eisenman: Feints, ed. by Silvio Cassarà (Milan: Skira, 2006), p. 196.

5 Carlo Giulio Argan, 'Sul concetto di tipologia architettonica', in Karl Oettinger, and Mohammed Rassem, eds, Festsschrift für Hans Sedlmayr (Munich: Beck, 1962), pp. 96-101. English translation: 'On the Typology of Architecture', trans. by Joseph Rykwert in Architectural Design, 33 (1963), 564-65 (p. 565).

${ }^{6}$ Argan's article has to be seen in context to Ernesto Rogers's 'Preexisting Conditions and Issues of Contemporary Building Practice' (1955), which formulates the concepts of continuità, and Saverio Muratori's morphological study of Venice in Studi per una operante storia urbana di Venezia (1960). They influenced the extension of typology to morphology, and a new rationality connecting architectural design strategies to that of the city. This is evident, for example, in discussions by Carlo Aymonino and Aldo Rossi of typology and morphology in 1963-65, and subsequently in Rossi's Architecture of the City (1966), Vittorio Gregotti's Il territorio dell'architettura (1966), and Giorgio Grassi's La costruzione logica dell'architettura (1967).

${ }^{7}$ Werner Oechslin, 'Premises for the Resumption of the Discussion of Typology' in Assemblage, 1 (1989), 36-53 and 'For a Resumption of the Typological Discussion' in Casabella, 509-510 (1985), 66-75.

${ }^{8}$ See Micha Bandini, 'Typology as a Form of Convention', AA Files, 6 (1984), 73-82 (p. 75).

9 These include Anthony Vidler, 'From the Hut to the Temple: Quatremère de Quincy and the Idea of Type', in The Writings of the Walls (New York: Princeton Architectural Press, 1987); 'The Idea of Type: The Transformation of the Academic Ideal, 1750-1830', Oppositions, 8 (1977); and 'The Third Typology', Oppositions, 7 (1976).

${ }^{10}$ For example Argan's 'On the Typology of Architecture' (1962), Rossi's Architecture of the City (1966), Colquhoun's 'Typology and Design Method' (1967), Vidler's 'The Third Typology' (1976), Moneo's 'On Typology' (1978), and Oechslin's 'Premises for the Resumption of the Discussion of Typology' (1989).

${ }^{11}$ Compare the most recent, comprehensive reassessments of the work of Le Roy and Quatremère by Christopher Drew Armstrong, Julien-David Leroy and the Making of Architectural History (2012) and Sylvia Lavin, Quatremère de Quincy and the Invention of a Modern Language of Architecture (1992).

${ }^{12}$ Claude Perrault, Ordonnance for the Five Kinds of Columns After the Method of the Ancients [Ordonnance des cinq espèces de colonnes selon la méthode des anciens, 1683]. Translated from French by Indra Kagis McEwan (Los Angeles: Getty Publications, 1993), p. 52.

13 This can be compared to Anthony Vidler's description of history and theory in Johann Joachim Winckelmann's work: 'The first was the body of rules governing taste, form, composition, propriety, and genre, generally understood as the 'theory of art'. The second was the account of the remains of the past commonly understood as 'history', sometimes chronological, sometimes heterotypical, sometimes arranged by juxtaposition, similarity, or resemblance.' In 'The Aesthetics of History', in The Writings of the Walls, p. 127.

14 This thesis anticipates Winckelmann's dogma in the History of the Art of Antiquity (1764) that all art historical enquiries ought to consider the context of a work of art through the culture, climate, and geography of the society that produced it.

${ }^{15}$ Julien-David Le Roy, The Ruins of the Most Beautiful Monuments of Greece [Les Ruines des plus beaux monuments de la Grèce: considérées du côté de l'histoire et du côté de l'architecture, 2nd edn, 2 vols, 1770]. Translated from French by David Britt (Los Angeles: Getty Research Institute, 2004), p. 210.

${ }^{16}$ Earlier comparative plates by Jacques Tarade, Juste-Aurèle Meissonnier, and Gabriel-Pierre-Martin Dumont, which are likely to be known to Le Roy, are surveyed by Robin Middleton in 'Introduction', The Ruins, pp. 90-97.

${ }^{17}$ Le Roy, Histoire de la disposition et des formes différentes que les Chrétiens ont données à leurs temples depuis le règne de Constantin le Grand jusqu'à nous (Paris: Desaint \& Saillant, 1764); as cited by Christopher Drew Armstrong in Julien-David Leroy and the Making of Architectural History (London: Routledge, 2012) p. 162.

18 As Le Roy explains, 'the forms of the buildings largely depend on climate and [that] the principles of architecture are not all so general that they do not sometimes give way before such influences'. The Ruins, p. 229.

${ }^{19}$ Michel Foucault, The Order of Things: An Archaeology of Human Sciences [Les Mots et les choses: une archéologie des sciences humaines, 1966]. Translated from French (New York: Pantheon Books, 1971; repr. 1994), p. 221.

20 The cultural anthropologist Melville Jean Herskovits distinguishes in the formation of culture by individuals of a society between socialisation (a formal social integration) and enculturation (an unconscious conditioning through customs that can change). Cultural change taking place as a result of exchange between different cultures is defined as diffusion (when a cultural transmission is achieved) or acculturation (when a cultural transmission is in process). See Man and his Works (New York: Alfred Knopf, 1948; repr. 1956).

${ }^{21}$ The Encyclopaedia, or a Systematic Dictionary of the Sciences, Arts, and Crafts (1751-72) by Denis Diderot and Jean-Baptiste le Rond d'Alembert eliminated Charles Batteux's category of the beautifying arts that previously included architecture and instead positioned it alongside the fine arts of music, painting, sculpture, and engraving.

${ }^{22}$ Antoine-Chrysostome Quatremère de Quincy, An Essay on the Nature, the End, and the Means of Imitation in the Fine Arts [Essai sur la nature, le but et les moyens de l'imitation dans les beaux-arts arts, 1823]. Translated from French by J. C. Kent (London: Smith, Elder and Co., 1837), p. 172.

${ }^{23}$ Quatremère, Essay on Imitation, p. 21.

${ }^{24}$ Quatremère, Essay on Imitation, p. 258.

25 'The words idea and image being synonymous, some metaphysicians have proposed to determine their variation, by applying the word idea to notions of intellectual objects, and the word image to those of corporeal objects.' Quatremère, An Essay on Imitation p. 212. 
26 'Type', in The True, the Fictive and the Real: The Historical Dictionary of Architecture of Quatremère De Quincy [originally in the Encyclopédie méthodique: Architecture, vol 3, 1825]. Translated from French by Samir Younés (London: Andreas Papadakis Publishers, 2000), p. 254.

27 'Type', p. 255.

28 'Type', p. 255.

${ }^{29}$ Legrand offered in 1799 a historical and theoretical text based on his planned work entitled Histoire générale de l'architecture to Durand. The essay was included with some first editions of the Collection and Parallel of Buildings and in 1809 published separately.

${ }^{30}$ Jacques-Guillaume Legrand, 'Essai sur l'histoire générale de l'architecture', in Jean-Nicolas-Louis Durand, Recueil et parallèle des édifices de tout genres, anciens et modernes, new edn. (Paris, 1809), as trans. by Anthony Vidler in 'The Idea of Type: The Transformation of the Academic Ideal, 1750-1830', Oppositions, 8 (1977), 94-115 (pp. 106-07).

31 Jean-Nicolas-Louis Durand, Précis of the Lectures on Architecture with Graphic Portion of the Lecture on Architecture Précis des leçons d'architecture données à l'École Royale Polytechnique, 1802-5 and Partie graphique des cours d'architecture faits à l'École royale polytechnique depuis sa réorganisation; précédée d'un sommaire des leçons relatives à ce nouveau travail, 1821]. Translated from French by David Britt (Los Angeles: The Getty Research Institute, 2000), p. 77.

32 Durand, Précis, p. 126.

33 This contradiction is pointed out by Leandro Madrazo in 'Durand and the Science of Architecture', Journal of Architectural Education, 48.1 (1994), 12-24.

${ }^{34}$ Durand, Précis, p. 180.

${ }^{35}$ Jean-Nicolas-Louis Durand, Partie graphique des cours d'architecture faits à l'École Royale Polytechnique depuis sa réorganisation; précédée d'un sommaire des leçons relatives à ce nouveau travail (Paris: the author, 1821). English translation: Précis, pp. 185-6.

${ }^{36}$ Semper's idea of the four elements was indebted to Gustav Klemm's anthropological work the General Cultural History of Mankind (1843-52), which coined a modern concept of culture as formed by society and its morals, laws, and customs, and described the houses of the South Pacific as centred around the hearth, elevated on earthen platforms, enclosed by walls made of wicker, and covered by a sparred timber roof. As Klemm claimed, art did not originate from fixed types but a primordial human need for representation that expressed itself as an artistic drive: 'We find the beginnings of art in the lowest stages of culture, where we also encounter the beginning of nations, because man has the urge to manifest his experiences externally, and to adorn his environment with these representations.' In Allgemeine Cultur-Geschichte der Menschbeit, I, p. 214, as cited by Mari Hvattum, in Gottfried Semper and the Problem of Historicism (Cambridge: Cambridge University Press, 2004), pp. 43-44.

${ }^{37}$ See The Four Elements of Architecture (1851), Science, Industry, and Art (1852), Theory of Formal Beauty (late 1850s).

${ }^{38}$ Gottfried Semper, 'Outline for a System of a Comparative Theory of Style' (1853). MS 122, fols. 5-6, in the Semper Archive, ETH. Reprinted in Gottfried Semper, Harry Francis Mallgrave, and Joseph Rykwert, 'London Lecture of November 11, 1853', RES: Anthropology and Aesthetics, 6 (1983), 5-31 (pp. 8-9).

${ }^{39}$ Semper, MS 122, fol. 15, repr. in 'London Lecture', p. 11.

${ }^{40}$ For the etymological argument see Gottfried Semper, Style in the Technical and Tectonic Arts; or, Practical Aesthetics, trans. by Harry Francis Mallgrave and Michael Robinson (Los Angeles: Getty Publications, 2004), p. 248.

41 'Style', in The True, the Fictive and the Real, p. 238.

42 Semper, MS 122, fols. 30-31, repr. in 'London Lecture', p. 16.

${ }^{43}$ Quatremère's library included La Rhetorique d'Aristote (Paris, 1822) with notes and an index of parallels in Cicero and Quintilian; see Fournel, Bibliothèque de M. Quatremère de Quincy de l'Académie des inscriptions et belles-lettres, secrétaire honoraire de l'Academie des beaux-arts (Paris: 1850), p. 27.

${ }^{44}$ Alan Colquhoun, 'Introduction: Modern Architecture and Historicity', in Essays in Architectural Criticism: Modern Architecture and Historical Change (Cambridge, MA: The MIT Press, 1981), p. 14. 